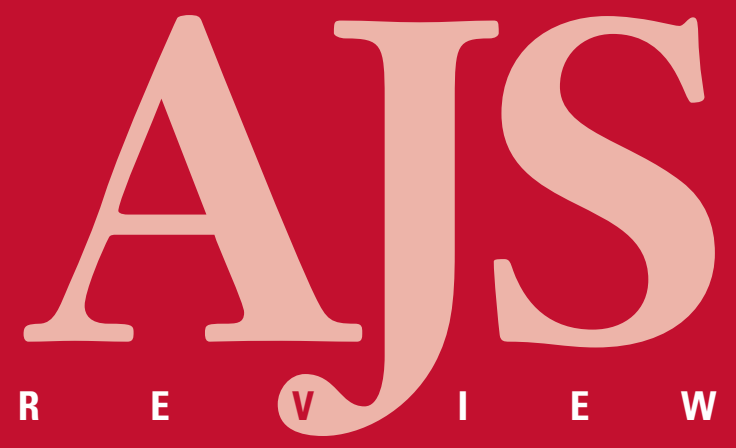

T A R T A R I A E

I M P E R I V M

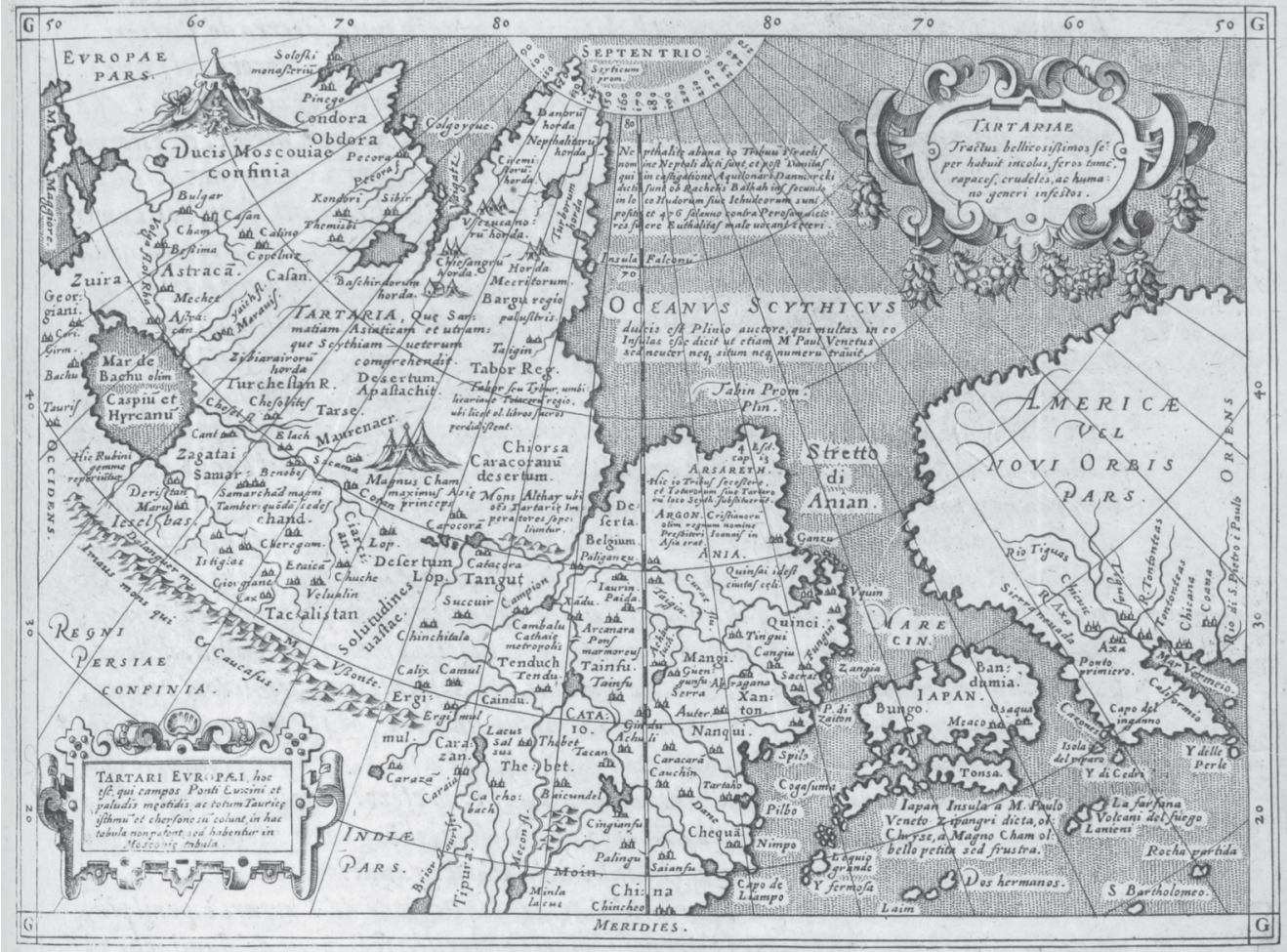

Tribes of Dan and Naphtali on the map of "Tataria Imperium" in Ptolemy, Geografia, cioè, Descrittione vniversale della terra (Venice: Gio. Battista \& Giorgio Galignani fratelli, 1598), courtesy Wesleyan University Library, Special Collections \& Archives. 


\author{
AJS Review \\ Association For Jewish Studies \\ New York, New York \\ EDITORS \\ Christine Hayes, Yale University \\ Magda Teter, Wesleyan University \\ Book REview EDITOR \\ Miriam Bodian, University of Texas at Austin \\ EDITORIAL BOARD \\ Michael Alexander, Temple University \\ Pamela Barmash, Washington University in Saint Louis \\ Yaakov Elman, Yeshiva University \\ Talya Fishman, University of Pennsylvania \\ Gershon David Hundert, McGill University \\ Riv-Ellen Prell, University of Minnesota \\ Jeffrey Rubenstein, New York University \\ Jeffrey Shandler, Rutgers University \\ Chava Weissler, Lehigh University \\ MANAGING Editor \\ Stanley Mirvis
}

The AJS Review (ISSN 0364-0094) is published twice annually by the Association for Jewish Studies

The AJS Review has been subsidized in part by a contribution from the Lucius N. Littauer Foundation.

Manuscripts for consideration should be e-mailed as a MS Word or rich text file to the AJS Review managing editor at ajsreview@ajs.cjh.org. Books for review should be sent to Miriam Bodian, AJS Review, Department of History, University of Texas, GAR 1.104, Mailcode B7000 Austin, Texas 78712

(C) the Association for Jewish Studies 2013. All rights reserved. No part of this publication may be reproduced, in any form or by any means, electronic, photocopy, or otherwise, without permission in writing from Cambridge University Press. Policies, request forms, and contacts are available at: http://www.cambridge.org/rights/permissions/permission.htm

Publishing, Subscription, and Advertising Offices: Cambridge University Press, 32 Avenue of the Americas, New York, NY 10013-2473, U.S.A.; or Cambridge University Press, The Edinburgh Building, Shaftesbury Road, Cambridge CB2 8RU, England.

Annual subscription rates for Volume 37, 2013: Institutions print and online $£ 114 / \$ 193$; institutions online only $£ 98 / \$ 168$; institutions print only $£ 104 / \$ 180$; single part $£ 57 / \$ 99$, payable in advance or on receipt of invoice; institutional check or credit card only. Special rates exist for members of the Association for Jewish Studies; membership information can be found at http://www.ajsnet.org. Information relating to AJS Review can be found at http://www.ajsnet.org/ajsreview.htm. AJS Review and all other Cambridge Journals can be found at http://journals.cambridge.org/

Photocopying Information: Permission to copy (for users in the U.S.A.) is available from Copyright Clearance Center, http://www.copyright.com, email: info@copyright.com.

Postmaster: Send address changes in the U.S.A., Canada, and Mexico to: AJS Review, Journals Dept., Cambridge University Press, 100 Brook Hill Drive, West Nyack, NY 10994-2133, U.S.A. Send address changes elsewhere to: AJS Review, Journals Dept., Cambridge University Press, The Edinburgh Building, Shaftesbury Road, Cambridge CB2 8RU, England. 


\section{AJS REVIEW}

The Journal of the Association for Jewish Studies

VOLUMe 37, Number 1

APRIL 2013

\section{Table of Contents}

\section{ARTICLES}

\section{Daniel Stein Kokin}

Toward the Source of the Sambatyon: Shabbat Discourse and the Origins

of the Sabbatical River Legend

David M. Goldenberg

"It is Permitted to Marry a Kushite"

Ilana Sasson

Gender Equality in Yefet 'Elı̄'s Commentary and Karaite Halakhah

\section{Ephraim Shoham-Steiner}

The Virgin Mary, Miriam, and Jewish Reactions to Marian Devotion in

the High Middle Ages

\section{Nicham Ross}

Can Secular Spirituality be Religiously Inspired? The Hasidic Legacy in the

Eyes of Skeptics.....

\section{Adam J. Sacks}

Hannah Arendt's Eichmann Controversy as Destabilizing Transatlantic Text.

Book ReVIEWS

Featured Reviews

Barry S. Wimpfheimer. Narrating the Law: A Poetics of Talmudic Legal Stories SteVen D. FraAde, Yale University ....

Stuart J. Hecht. Transposing Broadway: Jews, Assimilation, and the American Musical

Jeffrey Magee. Irving Berlin's American Musical Theater

STEPHEN J. WhitFIELD, Brandeis University

Jewish History and Rabbinic Culture in Late Antiquity

Ishay Rosen-Zvi. Demonic Desires: Yetzer Hara and the Problem of Evil in Late Antiquity

Marc Hirschman, Hebrew University of Jerusalem

Alexei M. Sivertsev. Judaism and Imperial Ideology in Late Antiquity

Beth A. Berkowitz, Barnard College 
Tzvi Novick. What is Good, and What God Demands: Normative Structures in Tannaitic Literature

YAIR FURSTENBERG, Hebrew University

Medieval and Early Modern Jewish History and Culture

Richard Hidary. Dispute for the Sake of Heaven: Legal Pluralism in the Talmud Tzvi Novick, University of Notre Dame

David H. Price. Johannes Reuchlin and the Campaign to Destroy Jewish Books JoHn SEWELL, University of California

Debra Kaplan. Beyond Expulsion: Jews, Christians, and Reformation Strasbourg

R. Po-Chia Hsia, Pennsylvania State University ....

Eric Nelson. The Hebrew Republic: Jewish Sources and the Transformation of European Political Thought

JEFFREY SHOUlson, University of Connecticut 160

Modern Jewish History and Culture

Michah Gottlieb. Faith and Freedom: Moses Mendelssohn's

Theological-Political Thought

BenJamin Pollock, Michigan State University

Rebecca Margolis. Jewish Roots, Canadian Soil: Yiddish Culture in Montreal, 1905-1945

IRA RoBInson, Concordia University.

Caitlin Carenen. The Fervent Embrace: Liberal Protestants, Evangelicals, and Israel

Stephen Spector, Stony Brook University

\section{Edited Volumes}

Elisheva Carlebach and Jacob J. Schacter, eds. New Perspectives on Jewish-Christian Relations. In Honor of David Berger AnNa SaPIR Abulafia, University of Cambridge.

Ra'anan S. Boustan, Oren Kosansky, Marina Rustow, eds. Jewish Studies at the Crossroads of Anthropology and History: Authority, Diaspora, Tradition AOMar Boum, University of Arizona

Hebrew Articles

עפר אליאור

א-כ

הוראת מדעים בחינוך הקראי: פרקים בלימוד הקראי של 'רוח חן'.

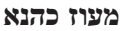

משנים את מידות העולם: פהני

כט-1ג חוג הלומדים המהפכני בקלויז ברודי ומה:תים ומהכת יחידות המידה בראשית העת החדשה.. 